\title{
Analysis of Self-Actualization Theory of Abraham Maslow and the Implication for Enhancement of Teacher's Competency
}

\author{
Ani Hendriani \\ Department of Pedagogy \\ Indonesia University of Education \\ Anihendriani@upi.edu
}

\begin{abstract}
Issues that being implicated in this study is still not optimal performance of teachers in developing their competence as a professional. A strong suspicion that there is a psychological factor that affects the performance of teachers, one of which is a low tolerance for failure neurosis that is individual to grow. This paper aims to present and analyze the selfactualization theory of Abraham Maslow and the implications for enhancement of teacher's competency. This research method is qualitative meta-analysis approach. This paper has practical significance as the foundation of education in development teacher's competency.
\end{abstract}

Keywords : Self-actualization, Abraham Maslow, Teacher's competency, meta-analysis.

\section{INTRODUCTION}

On Teacher's Day, 25 ${ }^{\text {th }}$ November 2016, there is an interesting quote from thousands Teacher's Day greeting that uploaded on social media. There was an educator wrote on Instagram, he said "whatever the meaning of Teacher. If their sweat no drips, streaks science poor of meaning, the spirit of learning dimming, mannerisms exemplary refraction, leaving no trace of the existence of inspiration. What is the meaning of being a teacher, if its presence is sorely missed. (Ibrahim, 2016). The phrase gives an illustration of how important a figure of teacher for the life, the teacher is the source of happiness and peace. The duties and roles of a teacher to educate the future generation is not easy, one fundamental condition is psychological health. According to Surya saving (2013, p.3-6) "Teachers in Indonesia are on the psychological dilemma is a condition in which teachers are faced with a state of dilemma, one side should stick to the norms of psychological ethics, but as a human being he has the quality certain psychological conditions. If the lack of psychological endurance prime, it can develop into a conflict, frustration, and even mental disorders. "Psychological disturbances in saving Maslow called Neurosis. Maslow states that the proper interpretation of neurosis is the failure of individuals to grow. This thinking is based on the assumption that every human being has the ability to continually grow and develop to his potential, or towards self-actualization which peaked. But at a time, the ability to grow is blasted in a sad situation and the fact that not as expected, it could be caused by another person or a specific event.

Maslow added that neurosis is a powerful destroyer of the efficiency of human choice to make your choice is good for their life. The impact will cause symptoms of alienation, life is meaningless, lost direction in life, an inability to enjoy life, inability to receive uniqueness and difference, bored, life tends to be worthless, empty, crisis philosophical, apathy, desecration of life, a spiritual crisis, depression, routines, feeling worthless, feeling needed, without hope, fear, doubt be everything, sarcastic, likes to complain, aimless, violence, habits destructive, and so on. (Maslow, 1976 p.141, Setiawan, 2014 , p.75). The antithesis of neurosis is the fulfillment of basic psychological needs, initiated by Abraham Maslow starting from physiological needs, safety, ownership (love), company needed to be appreciated, and self-actualization. Hierarchy psychological needs of Abraham Maslow became integrated human picture from a plurality of motivation, mental attitudes, ways of thinking, and the meaning of happiness.

Related with psychological theory of hierarchy needs of Abraham Maslow, the psychological condition of a teacher needs to be kept stable, one needs to be met is the need for selfactualization in order to improve the quality of teacher competence that is pedagogical, social, professional, and personable. Referring to the assumption that the author wanted to do a meta-analysis of self-actualization theory of Abraham Maslow and its implications for the enhancement of teachers competence.

\section{RESEARCH METHOD}

This study used a qualitative approach with a naturalistic paradigm for working in the background and a natural place (Creswell, 2014). Research methods using meta-analysis aimed to summarize the results of quantitative and qualitative research and then interpreting. This study attempted to summarize the self-actualization theory of Abraham Maslow has implications for enhancement of teachers competency. 


\section{RESULTS AND DISCUSSION}

\section{A. Self-actualization Theory}

As has been previously disclosed, that the company needed self-actualization is the culmination of Maslow's hierarchy of needs. The need for self-actualization will appear after four basic needs that exist beneath met (physical, safety, love, and self-esteem) gradually. Maslow's hierarchy of needs leads people to reach the pinnacle of his life is self-actualization. Maslow describe actualization ourselves by giving emphasis on integrated human-plenary (full-humanness), Carl Rogers called it with a fully functioning human being, Jung called it individual human, and Fromm calls it the autonomous human. (Setiawan, 2013, p.177)

To clarify the understanding of actualization himself, in his book The Farther of Human Nature, Maslow (1976, p.44-47) describe the behavior that appears on a experiencing actualization in "eight characteristics of habit". All these features will be the author of the interpretation in the description below:

- Self-actualization means experiencing fully, vividly, selflessly, with full concentration and total absorption.

The first characteristic of individuals with self-actualization is to understand the experience of his life fully. Reality conceived with full awareness, not distorted by the plight or negative things in the environment, because it has a healthy psychological condition. Individuals who have selfactualization can focus entirely on what he was doing, he was going to, because he was able to optimize all of their potential.

\section{- Second, let us think of life as a process of choices}

Self-actualization can also be defined as a process of life in determining the choices and solutive strategic. The journey of life is sometimes faced with a dilemma situation that requires intelligence and courage in taking a decision. The process of self-actualization will direct people to a decision based on the values of kindness. Because every decision is based on kindness will create happiness and sadness away. Individuals who toward self-actualization is always open to learning from life. His life is a life that continues to move towards a better, life is dynamic rather than static.

\section{- Third, to talk of self-actualization implies that there} is a self to be actualized

The third characteristic of individuals with selfactualization is the attempt to motivate yourself to discover your own potential is then generated through positive activities as a form of self-actualization.

\section{- Fourth, when in doubt, be honest rather than not}

The fourth characteristic of individuals who experience it have adequate self-actualization is the personal and social accountability. Individual responsibility symbolizes the character of honesty in the face of reality, even when in a state of doubt and fear even. They dared recognize mistakes openly, even able to laugh at himself. Social sense of responsibility symbolizes awareness (empathy) to the social life, community welfare, social mobility, and the progress of the nation. Individuals who experience selfactualization will always be agents of the good in any situation.

- Fifth, we have talked so far of experiencing without self-awareness, of making the growth choice rather than the fear choice, of listening to the impulse voices, and of being honest and taking responsibility.

The fifth characteristic of individuals with selfactualization is spontaneous in choosing towards growth rather than stagnation and setbacks. Self-actualization is marked with a trip to the top of the kindness, the trip culminated marked by achievement and works in accordance with its potential.

- Sixth, Self actualization is not only an end state but also the process of actualizing one's potentialities at any time, in any amount

After the verdict was set to continue to grow, individuals who undergo a process of self-actualization will always hone the potential for him under any circumstances. He has confidence, that the potential for a steady himself he was able to navigate the happy life. Such individuals do not want to get stuck in a routine and reliability without meaning. He is not satisfied with everything that instant, he enjoyed the process of peaking full of challenges and sacrifices. He has confidence that its potential will be honed to the right of self-actualization process and leads to goodness. This individual will enjoy her work, independent work, because working with potential and confidence will love.

\section{- Seventh, peak experiences are transient moments of self actualization}

Individuals who undergo a process of self-actualization slowly will have a peak experience of success. Peak experiences are experiences that are psychological and spiritual. Inner experience cannot be bought and obtained in an easy way. Maslow showed the phenomenon of peak experiences as a psychological situation also appear in religious experience, inner experience, which became the core of religious life. Maslow's thinking about peak experiences can be interpreted that individuals who undergo a process of self-actualization are likely able to find a touch of God in every inch of its existence. Selfactualization can foster psychological health that trigger one's religiousness. 
- Eighth, finding out who one is, what he is, what he likes, what he doesn't like, what is good for him and what bad, where he is going and what his mission is - opening oneself up to himself-means the exposure of psychopathology.

Last characteristic of individuals with self-actualization is he was able to discover the identity. This capability with respect to awareness of the advantages and disadvantages of self. The advantages of self is always the potential that must be honed. While awareness of the weaknesses of identification starts self defense, then the courage to release it, fight it, and then slowly heal. Awareness of the weaknesses is the beginning of a movement towards the development of life toward the top of kindness.

Related with the description above, the authors conclude that self-actualization is defined as a person's ability to find identity both advantages and drawbacks. Excess assets will be manifested in the development of potential non-stop, the goal is to develop life towards happiness and social self. Every inch of the journey of life is defined as the process of peaking and not frozen. Therefore, these individuals have accountability and integrity of personally and socially for always being an agent spreader values of kindness. Further weakness he made reflections to improve the spiritual experience in the process of self-healing. He would bend over the heart to reduce or eliminate the negative things in themselves. Courage in releasing and healing weakness makes it depend on the Lord in prayer and endeavor. So that the peak will experience that he acquired sufficient experience of spirituality that will take him into the process of perfecting themselves to be fully human.

\section{B. Implication of Self-actualization on the enhancement of teachers competency}

The importance of the role of teachers in education mandated by the Law of the Republic of Indonesia Number 14 Year 2005 on Teachers and Lecturers, which mandates their coaching and professional development of teachers as the actualization of a professional educator. The sound of RI Law No.14 of 2005 points b, namely:

"Considering it would need to be done by empowering and increasing the quality of teachers and lecturers are planned, directed, and sustainable; that teachers and lecturers has the function, role and strategic position in the national development in the field of education as referred to in a letter that needs to be developed as a dignified profession"

To realize the mandate of the law as intended, the Ministry of Education and Culture to implement Teacher Competency Enhancement Program for all teachers, either already certified or not certified. In saving Majid (2007, p.5) "competence is a set of full-hearted jab intelligent action one should have as a requirement to be considered able to perform tasks in a particular field". Meanwhile, according to Usman (Wibowo, 2006, p.4) competence is defined as something that describes a person's qualifications or abilities, both qualitatively quantitatively ". Based on those two opinions can be defined as the capacity of individuals to do a performance in a field and is manifested in a performance that has the same quality and quantity of good.

Related with the notion of competence, within the mandate of PP No. 74 of 2008 on Standards of Teachers and Education Personnel mentioned in article 28, paragraph 3 that: Teachers at every level of education must have four competency includes pedagogical competence, personal competence, professional competence and social competence. (Tim MKDP UPI, 2008). To develop the competence fourth, teachers need a proper process of self-actualization. In this section the authors sought to describe Abraham Maslow's theory of selfactualization and the implications for the development of teacher competence.

\section{Pedagogic Competency}

According Wibowo (2012) Pedagogic Competence is the ability of teachers with regard to:

- multidimensional understanding of the characteristics of learners, both from the philosophical dimension, psychological, social, and cultural.

- designing and implementing learning process in accordance with the educational theories of learning relevant

- able to manage the class well

- implement learning assessment both process and outcome

- development of learners to actualize various potentials.

Referring to the characteristics of the pedagogic competence, self-actualization form that must be done by the teacher is aware of its role as a pedagogue (educator) whose job lead learners towards maturity to think, behave and act. Not only maturity, teachers should also be aware that he was also tasked to develop all the potential of the learners so that could be a whole human that is ready to compete and exist in the social environment the Community. Teachers should be aware that every action performed in the educational process is an obligation to be accountable before God. So the spirit of educating the young generation will remain intact amid a variety of psychological conflicts that hit.

After realizing her role as a teacher, the next step is to continue to hone their potential through improved teaching skills. Conventional learning approaches must be abandoned and switch on the learning pedagogical (educational). Learning approach should be developed to print generation and superior moral nation among which the scientific approach, multiliteracy, thematic-integrated, cooperative learning, and learning-based national character.

Strategy to sharpen our potential in the learning process is through PTK. According to Mc. Niff (Basrowi, 2008: 27) 'PTK is shaped reflective intensive search conducted by the teachers themselves, the results can be utilized as a tool for curriculum development, school development, the development of teaching skills, and so forth'. Through PTK teachers will reflect 
on the process of teaching which he did, to identify strengths and weaknesses, determine the cause, as well as designing solutions to improve the quality of the learning process.

\section{Personality Competency}

According Wibowo (2012) Competence personality is a personal capacity reflects the personality:

- steady, stable according to the norm of law, social norms and have consistency in action.

- adult means to have the independence in the act

- wise means to show openness in thinking and acting

- authoritative means to have a positive effect on the behavior of learners and respected

- become role models for students and noble means to act in accordance with religious norms (IMTAQ, honest sincere) and have exemplary behavior of learners)

Related with personality competencies, forms of selfactualization to do the teacher is aware of its role as a moral agency in various dimensions of life. According to Campbell (2003) "Moral agency is a double condition surrounding the teacher as a figure of moral conduct ethical professional conduct as well as moral educator who teaches students the virtues and the same core principles and fought to enforce in practice". Furthermore Campbell (2001) asserts that as moral agency, the teacher must have a high level of moral awareness. In this case, the level of awareness is embedded when teachers develop the capacity to identify how the values and moral principles and ethics exemplified through actions, words, decision-making, and their own intentions. Such relationships are created in intellectual, emotional, intuitive, philosophy, practices, and experiential when teachers reflect individual and collective discussions with colleagues about the job that they see themselves wrestled every day.

\section{Professional Competency}

According to Alma (Wibowo 2012) is the ability of professional competence with regard to mastery learning materials field of study is broad and deep mastery of the substance that covers the material content in the school curriculum subject and substance of knowledge that overshadow the curriculum materials, and also mastery on the structure and methodology of science.

Referring to the professional competence put forward by Alma, it can be understood that the form of self-actualization can be done by the teacher is to live his work as a profession. In order for a profession can produce a good quality product, it needs to be coupled with a strong work ethic as well. There are three basic characteristics which are always viewable on any good professional about his work ethic, namely: 1) the desire to uphold the quality of work, 2) keep themselves in work execution, 3) the desire to provide services to the public. Furthermore, in the opinion of Egan, Kayhan, and Ramirez (2004, hlm.304) "Many professions which sets out the rules, which include admission standards, codes of conduct and certification exams to provide assurance to the public that this profession is managed seriously. It means being a professional is not just an intellectual process, but also a process of social and moral ". Forms of self-actualization that can be done is to improve the performance of teachers in the social environment of education, good nature involve a process of intellectual, social, moral, operational, and administrative.

\section{Social Competency}

According to Alma (Wibowo, 2012) Social competence with respect to the ability of educators (teachers) as part of the community to communicate and interact effectively with students, fellow teachers, staff, parents / guardians of students and society.

To improve social competence, teachers must constantly improve intelligence actualize himself with social and interpersonal skills. Teachers must have the skills to communicate, interact, collaborate, and build cohesiveness in educational environments be it family, school and society.

\section{CONCLUSION}

Teacher is a generator advancement of education, and education is the parameter progress of a nation. Teachers should always be able to perform self-actualization process with a variety of activities that can hone potential, skills, and competence as a professional. Forms of self-actualization can be started on building awareness of the fundamental role as a teacher, then devise strategic measures to increase the competence, and the latter as a reference reflect improvements in education. Teachers who have self-actualization will constantly learn and fight for emancipation in order to improve the quality of education.

\section{REFERENCES}

[1] Basrowi, H. dan Suwardi. (2008). Prosedur Penelitian Tindakan Kelas. Bogor : Ghalia Indonesia

[2] Campbell, E. (2001). Let right be done : Trying to put Ethical standars into practice. Journal of educational policy.

[3] Campbell, E. (2003). The Ethical Teacher. Maidnelead. UK : Open University Press

[4] Creswell, J.W.(2014). Penelitian Kualitatif \& Desain Riset (Memilih lima Pendekatan). Yogyakarta : Pustaka Pelajar

[5] Egan, E.A. Kahyan, P \& Ramirez (2004). Comparing ethics education in medicine and law. Annals of health, 13,303-325.

[6] Ibrahim, T. (2016). https://www.instagram.com/teguh.ibrahim.( di akses tanggal 25 november 2016)

[7] Majid, (2007). Perencanaan Pembelajaran Mengembangkan Standar Kompetensi Guru.Bandung : Rosda Karya

[8] Maslow, A. (1976).The Farther Reaches of Human Nature. New York : Penguin Compas

[9] Setiawan, H. (2014). Manusia Utuh (Sebuah Kajian atas Pemikiran Abraham Maslow).

[10] Surya, M. (2013). Psikologi Guru Konsep dan Aplikasi dari Guru untuk Guru. Bandung : Alfabeta.

[11] Tim MKDP UPI (2008). Landasan Pendidikan. Bandung : UPI PRESSS

[12] Wibowo, A. (2012). Menjadi Guru Berkarakter. Yogyakarta : Pustaka Pelajar 